\title{
Haematological Changes during Fracture Healing in Goats
}

\author{
Dharmendra Kumar ${ }^{1}$, M.K. Bhargava ${ }^{2}$, Randhir Singh ${ }^{3}$, Apra Shahi ${ }^{4}$, \\ J. Aparajita ${ }^{5}$ Madhu Swami ${ }^{6}$, S.K.Jain ${ }^{7}$, M.L.V.Rao ${ }^{8}$, and A.P. Singh ${ }^{9}$ \\ ${ }^{1-4}$ Department of Surgery and Radiology, ${ }^{5}$ Department of Biotechnology, T.M. Bhagalpur, ${ }^{6}$ Department of \\ Veterinary Pathology, ${ }^{7}$ Department of Veterinary Gynecology, ${ }^{8}$ Department of Veterinary Medicine, ${ }^{9}$ \\ Biotechnology Centre College of Veterinary Science and Animal Husbandry, N.D.V.S.U., Jabalpur
}

\begin{abstract}
Apparently healthy goats of either sex, aged between one to six years were selected for present study Fracture segment of these animals were brought into apposition and immobilized by dynamic compression plate $(D C P)$. Haematological parameter such as total erythrocyte count (million/ $\mu l)$, total leucocyte count (thousand/ $\mu l)$, differential leucocyte count (per cent), haemoglobin $(\mathrm{g} / \mathrm{dl})$ and packed cell volume (per cent) were determined pre-operatively and on $7^{\text {th }}, 15^{\text {th }}, 30^{\text {th }}, 45^{\text {th }} 60^{\text {th }}$ and $90^{\text {th }}$ post- operative day. A non significant decrease in the values of total erythrocyte count, Haemoglobin and Packed Cell Volume, was observed on $7^{\text {th }}$ post-operative day followed by fluctuation of the values within normal physiological range. Total leucocyte count, neutrophil and eosinophil count showed non-significant increase from 0 to $7^{\text {th }}$ day interval. However these values were within normal physiological reference range. Lymphocyte count showed non-significant decrease on $7^{\text {th }}$ day thereafter, significant increase $(p<0.5)$ was observed from $15^{\text {th }}$ day onwards. The basophil and monocyte count also showed non-significant variation at different time intervals.
\end{abstract}

Keywords: Fracture, Haematological parameters, Total erythrocyte count, Total leucocyte count, Differential leucocyte count.

\section{Introduction}

Bone is a multifunctional tissue that provides structure to the body. It acts as a protective cage for visceral organ, acts as a fulcrum for the muscles, a store house of calcium, phosphorous and is the site of formation of blood and immune cells (Caplan, 1991 and Hing 2004). Bone can be classified as dense cortical or lamellar and cancellous or trabecullar. Cortical or lammelar bone is responsible for the mechanical strength, whereas trabecular bone is composed of a network of spicules with empty space that contains bone marrow and it forms the central core of bones.

Fracture is the breach in the continuity of hard tissue. Bone is unique among tissue, in that it heals by regeneration and not by scar formation as is evident in muscle, skin, heart etc. Traumatic injuries are the major source of bone fracture. These injuries can occur in several situations and impair the patient's ability to perform their normal day to day activities.

Goat plays a pivotal role in supporting the livelihood of rural, tribal, nomadic and semi-nomadic population. These people frequently wander in and around urban vicinity, where their animal gets encountered with automobile accident leading to fracture of bones. Although automobile accident plays a major contributory factor for fracture in goats other factors such as falling from height, jumping, intentional kicking and fight between animals are too responsible for this condition. Fracture of long bones often compels the owner to sale their only source of income at lower price, which causes economic loss to them.

Haematological parameters play a key role for monitoring fracture healing. Any deviation from normal physiological reference range is often an indication of an infection and it requires an immediate attention, failure to which would lead delayed union, non-union and mal-union. The haemogram is the mirror of the happening in the body and it particularly guides and directs clinicians towards the health status of the body.

Fracture repair can be divided into three phases, inflammatory, reparative and remodeling phase and these haematological attributes are responsible for completion of all these three phases.

\section{Materials and Methods}

Six clinical cases of goats having long bone fracture presented at Teaching Veterinary Clinical Complex, College of Veterinary Science and Animal Husbandry, Jabalpur, during the study period were included in the present study. Apparently healthy goats of either sex, aged between one to six years were selected for present study Fracture segment of these animals were brought into apposition and immobilized by dynamic compression plate (DCP).

Five milliliter of blood was collected from jugular vein of each animal pre-operatively and on $7^{\text {th }}, 15^{\text {th }}$, $30^{\text {th }}, 45^{\text {th, }} 60^{\text {th }}$ and $90^{\text {th }}$ post- operative day for analysis of hematological attributes. Haematological parameter such as total erythrocyte count (million/ $\mu \mathrm{l}$ ), total leucocyte count (thousand/ $\mu 1$ ), differential leucocyte count (per 
cent), haemoglobin $(\mathrm{g} / \mathrm{dl})$ and packed cell volume (per cent) were determined as per method described by Chauhan and Chandra (2007).

\section{Results and Discussion}

The changes in mean \pm SE of haematological parameters at different time intervals are presented in Table - 01. A non significant decrease in the values of total erythrocyte count, Haemoglobin and Packed Cell Volume, was observed on $7^{\text {th }}$ post-operative day followed by fluctuation of the values within normal physiological range. The above findings were in accordance with the findings of Aithal et al. (1998), Tembhurne et al. (2010) and Rajhans (2013) in dogs, Kumar et al. (1999) in calves and Gabriel et al. (2014) and Gupta (2015) in goats, who also reported non-significant difference in the values of these parameters and the values fluctuated within normal physiological limit.

A transient decrease in the value of total erythrocyte count in the present study may be attributed to trauma suffered by the goats during fracture and loss of blood pre-operatively and during the surgical procedure.

Table 01: Mean values ( \pm SE) of complete blood count at different time intervals

\begin{tabular}{|l|l|l|l|l|l|l|l|l|l|}
\hline Days & TEC & Hb & PCV & TLC & N & L & E & B & M \\
\hline $0^{\text {th }}$ & 12.68 & 10.47 & 31.07 & $14.00^{\mathrm{a}}$ & $49.33^{\mathrm{a}}$ & $48.83^{\mathrm{a}}$ & 1.50 & 0.00 & 0.33 \\
& \pm 1.31 & \pm 0.92 & \pm 2.33 & \pm 0.95 & \pm 3.14 & \pm 3.26 & \pm 0.34 & \pm 0.00 & \pm 0.21 \\
\hline $7^{\text {th }}$ & 11.31 & 9.53 & 27.67 & $16.22^{\mathrm{a}}$ & $55.67^{\mathrm{a}}$ & $41.17^{\mathrm{a}}$ & 2.17 & 0.00 & 1.00 \\
& \pm 0.88 & \pm 0.53 & \pm 2.01 & \pm 1.34 & \pm 4.12 & \pm 4.51 & \pm 0.17 & \pm 0.00 & \pm 0.26 \\
\hline $15^{\text {th }}$ & 13.48 & 10.90 & 32.67 & $10.83^{\mathrm{b}}$ & $36.33^{\mathrm{b}}$ & $61.50^{\mathrm{b}}$ & 1.50 & 0.17 & 0.50 \\
& \pm 0.54 & \pm 0.41 & \pm 1.23 & \pm 0.73 & \pm 2.39 & \pm 2.20 & \pm 0.22 & \pm 0.17 & \pm 0.22 \\
\hline $30^{\text {th }}$ & 13.89 & 10.87 & 32.33 & $9.27^{\mathrm{b}}$ & $32.17^{\mathrm{b}}$ & $66.00^{\mathrm{b}}$ & 1.17 & 0.17 & 0.50 \\
& \pm 0.36 & \pm 0.47 & \pm 1.05 & \pm 0.58 & \pm 2.18 & \pm 2.13 & \pm 0.17 & \pm 0.17 & \pm 0.22 \\
\hline $45^{\text {th }}$ & 13.97 & 11.27 & 32.93 & $9.61^{\mathrm{b}}$ & $32.17^{\mathrm{b}}$ & $65.83^{\mathrm{b}}$ & 1.33 & 0.00 & 0.67 \\
& \pm 0.83 & \pm 0.47 & \pm 1.09 & \pm 0.59 & \pm 1.62 & \pm 1.33 & \pm 0.33 & \pm 0.00 & \pm 0.21 \\
\hline $60^{\text {th }}$ & 13.76 & 11.10 & 32.33 & $8.83^{\mathrm{b}}$ & $31.17^{\mathrm{b}}$ & $67.00^{\mathrm{b}}$ & 1.17 & 0.17 & 0.50 \\
& \pm 0.39 & \pm 0.31 & \pm 0.92 & \pm 0.74 & \pm 2.65 & \pm 2.91 & \pm 0.31 & \pm 0.17 & \pm 0.22 \\
\hline $90^{\text {th }}$ & 13.29 & 10.85 & 31.33 & $8.17^{\mathrm{b}}$ & $30.17^{\mathrm{b}}$ & $68.67^{\mathrm{b}}$ & 1.00 & 0.00 & 0.17 \\
& \pm 1.12 & \pm 0.82 & \pm 2.24 & \pm 0.56 & \pm 1.92 & \pm 1.78 & \pm 0.26 & \pm 0.00 & \pm 0.17 \\
\hline
\end{tabular}

- Values having different superscript ab shows significant difference at $5 \%$ level between intervals

Total leucocyte count showed non-significant increase from 0 to $7^{\text {th }}$ day interval. Thereafter, the values decreased significantly $(\mathrm{p}<0.5)$, from $15^{\text {th }}$ day onwards. These findings were in accordance with the findings of De'Souza (2012), Rajhans (2013), Toth et al. (2014), and Singh (2015) in canines and Gabriel et al. (2014) and Gupta (2015) in goats, who also reported slight increase in total leucocyte count post-operatively.

Non-significant increase in neutrophil count was observed on $7^{\text {th }}$ day, followed by significant decrease $(\mathrm{p}<0.5)$ from $15^{\text {th }}$ day onwards. Comparison between groups showed non-significant difference between them.

Tembhurne et al. (2010), De'Souza (2012), Rajhans (2013) and Singh (2015) in canine and Gupta (2015) in goats, also observed increase in the value of neutrophil, just after surgery followed by a decrease, after which it fluctuated within normal range.

Increase in the value of neutrophil just after surgery might be due to fact that neutrophils are considered as the first line of defense of the body, therefore an increase in its value is seen just after onset of inflammation, aided by release of chemical mediators of inflammation i.e. bradykinin, cytokines, 5-HT (5- hydroxytryptamine) and prostaglandin of wound hormones i.e. trephones (Schalm et al., 1975 and Sastry, 1983).

Lymphocyte count showed non-significant decrease on $7^{\text {th }}$ day thereafter, significant increase $(\mathrm{p}<0.5)$ was observed from $15^{\text {th }}$ day onwards. These findings were similar to the findings of Aithal et al. (1998) Tembhurne et al. (2010), Rajhans (2013) and Singh (2015) in dogs, Kumar et al. (1999) in calves and Gupta (2015) in goats.

The decrease in lymphocyte count on $7^{\text {th }}$ day can be attributed to inflammatory reaction caused as a result of surgical intervention, which in turn activates the production of immune-regulatory cytokines by macrophage and monocytes. Cytokines are responsible for activation of adrenal axes and in turn increases the production of gulcocoticoides. Increase in the concentration of gulcocorticoides might be responsible for lyses of lymphoid tissue and lysis of circulating lymphocytes (Kaneko, 1997).

Non-significant increase in eosinophil count was observed on $7^{\text {th }}$ day interval. However, the values fluctuated within normal reference range.

These findings are in accordance with the findings of Kumar et al. (1999) in calves, Desouza (2012), Rajhans (2013) and Singh (2015) in dogs and Gabriel et al. (2014) and Gupta (2015) in goats, who were of opinion that the value of eosinophil fluctuates within normal physiological range during fracture healing.

The basophil count also showed non-significant variation at different time intervals. These findings corroborated the findings of De'Souza (2012) and Singh (2015) in dogs and Gupta (2015) in goats, who reported non-significant variation in the values of basophil count. 
Monocyte count showed non-significant difference at different time intervals.These findings were similar to the findings of De'souza (2012), and Singh (2015) in dogs and Gupta (2015) in goats, who reported non-significant variation in the values of monocyte count.

\section{References}

[1] Aithal, H.P., Singh, G.R. and Bisth, G.S. (1998). A comparative study for supracondylar fracture in dog. Indian Journal of Veterinary Surgery, 19: $84-89$.

[2] Caplan, A.I. (1991). Mesenchymal stem cells. Journal of Orthopaedic Research, 9 (5): 641-650

[3] Chauhan, R.S. and Chandra, D. (2007). Veterinary Laboratory Diagnosis, $2^{\text {nd }}$. Edn., International book distributing co., New Delhi, pp 11-28, 99-124.

[4] De'Souza, F. (2012). Internal fixation of distal third fracture of long bone in dogs. M.V.Sc. \& A.H. thesis (Surgery and Radiology), Nanaji Deshmukh Veterinay Science University, Jabalpur.

[5] Gabriel, O., Hassan, A.Z., Abdullahi, U.S. and Fatihu, M.Y.( 2014). Changes in body and haematological parameters following the use of bone plates in management of tibial fracture in kano brown goats. Journal of Animal and Veterinary Advances, 13 (9):549597.

[6] Gupta, S. (2015). Fracture healing using biphasic calcium phosphate with dynamic compression plating in goats. M.V.Sc. \& A.H. thesis (Surgery and Radiology), Nanaji Deshmukh Veterinay Science University, Jabalpur.

[7] Hing, K.A. (2004). Bone repair in the twenty-first century: Biology, chemistry or engineering. Philosophical Transactions: A Mathematics Physics English and Science Journal, 362 (1825): 2821-2850.

[8] Kaneko, J. (1997). Carbohydrate metabolism and its disease: Blood glucose in animals. Text Book of Clinical Biochemistry of Domestic Animals. $5^{\text {th }}$ edn. Elsevier publishers, Philadelphia, U.S.A., pp 64.

[9] Kumar, V., Varshney, A.C., Singh, M., Sharma, S.K. and Nigam, J.M. (1999). Haemato-biochemical changes during fracture repair with hydroxyapatite -fibrillar collagen implants in calves. Indian Journal of Veterinary Surgery, 20 (2): $92-93$.

[10] Rajhans, M. (2013). Stabilisation of splinters of long bone fracture in dogs. M.V.Sc. \& A.H. thesis (Surgery and Radiology), Nanaji Deshmukh Veterinay Science University, Jabalpur.

[11] Sastry, G.A. (1983). "Haematology "In: Veterinary Clinical Pathology. C.B.S. Publishers and distributors Pvt. Ltd., Delhi, pp20.

[12] Schalm,O.W., Jain N.C. and Carrol, E.J.(1975). In: Veterinary Haematology $3^{\text {rd }}$ Edn., Lea and Febiger Publishers, Philadelphia, pp 807.

[13] Singh, R. (2015). Composite mesh guided tissue regeneration for fracture repair in dogs. Ph.D.. thesis (Surgery and Radiology), Nanaji Deshmukh Veterinay Science University, Jabalpur.

[14] Tembhurne, R.D., Gahlod, B.M., Dhakate, M.S., Akhre, M.S. Upadhye, S.V. and Bawaskar, S. (2010). Management of femoral fracture with the use of horn peg in canine. Veterinary World, 3 (1): 37-41.

[15] Toth , C., Klarik, Z., Kiss, F., Toth, E., Hargitai, Z. and Nemeth, N. (2014). Early post-operative changes in haematological, erythrocyte aggregation and blood coagulation parameters after unilateral implantation of polytetrauroethylene vascular graft in femoral artery of beagle dogs. Acta Cirurgica Brasileira, 29: (5): 320-327. 